\title{
Single and Multiple Portfolio Cross-Hedging with Currency Futures*
}

\author{
Andrea L. DeMaskey \\ Villanova University, U.S.A.
}

This article presents empirical evidence on the effectiveness of currency futures cross-hedging with the portfolio model. Single and multiple crosshedges for three minor European and three minor Asian currencies are examined. The performance of the cross-hedged portfolios is measured in terms of maximum possible variance reduction. Realistic simulations of crosshedging effectiveness are used to determine how well the optimal portfolio strategy performs relative to not hedging or a naive cross-hedge. Results show that Asian currency risk cannot be minimized with single or multiple currency futures cross-hedges. Indeed, both the naive and portfolio strategies increase exchange rate risk to the hedger. Because of the diversification benefit, the multiple currency cross-hedge is superior in hedging performance to the single currency cross-hedge. However, a cross-hedge constructed with two different currency futures positions is as effective as one with five different futures contracts. While the cross-hedge ratios of the European currencies are unstable over time, cross-hedging effectiveness appears not to have been affected significantly.

\section{Introduction}

To remain cost-competitive at home and abroad, many companies have been forced to increase their global sourcing and shift production overseas. The most promising markets today are in third-world countries that offer a large human resource base and, most importantly, labor at relatively low costs. As companies exploit the advantages offered by these countries, the nature and

\footnotetext{
* Earlier versions of the article were presented at the 1995 annual conference of the Multinational Finance Society in Philadelphia and at the 1994 annual meeting of the Financial Management Association in St. Louis. I thank the session participants, two anonymous reviewers of the Journal and the editor in charge of the manuscript for helpful comments and Villanova University for financial support. Any errors remaining are my responsibility.
}

(Multinational Finance Journal, 1997, vol. 1, no. 1, pp. 23-46)

(C) by the Multinational Finance Society, a nonprofit corporation. All rights reserved. DOI: $10.17578 / 1-1-2$ 
volume of their third-world trade and capital flows increase. At the same time, traders and investors engaged in international transactions with less developed countries find themselves exposed to exchange rate risk that cannot easily be hedged in the international financial markets. While forward contracts up to six months may be available in these minor currencies, forward markets tend to be thin and less liquid at increasing contract maturity. Exchange-traded derivatives, such as currency futures and options, interbank options, and swap arrangements, are either limited or nonexistent. ${ }^{1}$ In addition, exchange controls and other regulations can severely restrict the activities of the foreign exchange market. To cope with these challenges, market participants are forced to take a more dynamic attitude to managing foreign exchange rate risk.

Cross-hedging is a risk management tool that is used to minimize exchange rate risk when the expected cash flows are denominated in a minor currency. For example, a company with a contractual obligation to take a long position in the Spanish peseta or South Korean won may want to protect its cash position with a currency hedge. Since derivative instruments on these currencies are not available, the currency spot position can be covered with a futures contract in a different currency, e.g., the German mark or the Japanese yen. The effectiveness of structuring this cross-hedge depends on four interrelated issues: (1) the degree to which the spot and futures currencies are positively correlated; (2) the accuracy of estimated risk-minimizing cross-hedge parameters; (3) the stability of the optimal cross-hedge ratios over time; and (4) the potential risk reduction from portfolio cross-hedging.

The objective of the article is to present empirical evidence on crosshedging with the portfolio model in the currency futures market. Single and multiple cross-hedges for spot currencies without futures contracts are examined. ${ }^{2}$ Hedging effectiveness is measured as the percentage reduction in the variance of a hedged portfolio relative to that of an unhedged spot position. Based on simulations of hedging performance, the results of the portfolio strategy are compared with those of a naive hedge strategy and an unhedged position. Ex ante cross-hedging effectiveness is emphasized using a relatively large sample size.

Numerous studies of currency futures hedging and cross-hedging have generally adopted the mean-variance methodology developed by Markowitz (1952) and applied to futures by Ederington (1979), Johnson (1960) and Stein (1961). The single futures hedge approach was extended to a multivariate

1. The information was gathered from various supplemental issues of Euromoney (1995, 1996).

2. A single cross-hedge involves covering a single currency spot position with a single futures position in a different currency. In a multiple cross-hedge, the single currency spot position is hedged with multiple futures positions in different currencies. 
framework by Anderson and Danthine (1981), who also examined crosshedging strategies. Results of earlier studies focused on ex post measures of optimal hedge ratios and hedging effectiveness (e.g., Dale 1981; Grammatikos and Saunders 1983; and Hill and Schneeweis 1981, 1982). Although most of these studies suggested currency futures hedging strategies to be effective, their approach offered little guidance to the actual hedger who needs to know the minimum risk hedge ratio a priori. Of course, it is not possible to implement optimal hedge ratio estimates ex ante. Thus, it was reasonable to expect that real world hedging effectiveness would be lower.

The need to conduct tests under more realistic hedging conditions prompted several researchers to examine least-risk hedge ratios and hedging performance for currency futures hedging and cross-hedging on an ex ante basis (e.g., Marmer 1986; Eaker and Grant 1987, 1989; Park, Lee and Lee 1987; Lypny 1988; Braga, Martin and Meilke 1989; Braga and Martin 1990; Malliaris and Urrutia 1991; Benet 1990a, 1990b, 1992). The results reported by Eaker and Grant (1987, 1989) and Benet (1990a, 1990b, 1992) showed a significant difference between ex post and ex ante hedging effectiveness measures. Such a discrepancy in performance was greatest in the presence of intertemporal hedge ratio instability. In fact, many researchers found the hedge ratio variability problem to be significant, particularly when cross-hedging foreign exchange rate risk (e.g., Grammatikos and Saunders 1983; Marmer 1986; Eaker and Grant 1987, 1989; Kwok 1987; Park, Lee and Lee 1987; Braga, Martin and Meilke 1989; Benet 1990b; Malliaris and Urrutia 1991). In this case, the economic relation between the currency and the cross-hedging instrument may be weak and less stable, thereby causing the estimated least-risk hedge ratio to be unreliable on an ex ante basis.

Even if the optimal hedge ratio is stable over time, the portfolio model hedge strategy must be evaluated for its ability to minimize foreign currency exposure. Superior hedge performance is attainable only as long as the portfolio model yields least-risk hedge parameters for a given hedge period. Based on realistic simulations of hedging performance, Marmer (1986), Kwok (1987), Eaker and Grant (1989), and Braga and Martin (1990) compared the portfolio hedge with a naive hedge rule and no hedge. Their findings offer overwhelming support for the usefulness of the portfolio model strategy for out-of-sample currency futures and currency cross-hedges.

This article extends the evidence on the effectiveness of currency crosshedging in several ways. First, it examines minor European and Asian currencies that are identified as having a strong positive correlation with currency futures contracts. Second, it examines single and multiple currency futures cross-hedges within a mean-variance framework. And third, a simulation is run to compare the ex ante hedging effectiveness of the portfolio model strategy with a naive hedge strategy and an unhedged position. 
The article is organized as follows. Section II describes the data and statistical method used in this study. The empirical results are presented in section III. Section IV provides a summary of the study and a conclusion for policy makers.

\section{Data and Method}

The data include monthly spot prices for the Italian lira, Spanish peseta, Greek drachma, Singapore dollar, South Korean won, and Hong Kong dollar and are obtained from the International Financial Statistics and the Trade Data Bank. British pound, Canadian dollar, German mark, Japanese yen, and Swiss franc futures prices are provided by the Futures Industry Institute Data Center. Prices are all closing or settlement prices in U.S. dollar per foreign currency collected monthly for the last day of the month. The data cover the period January 31, 1983, through December 31, 1992. Currency futures are available with four maturity months: March, June, September, and December. Thus, for each contract, as suggested by Eaker and Grant (1987, 1989), the holding periods run for the three months prior to the maturity date with 12 monthly (non-overlapping) holding periods during each of the ten years (120 observations each for the currency futures).

A hedger is defined as one who minimizes the variance of expected dollar returns on a currency spot position with respect to a position in the currency's corresponding future contract (e.g., Ederington 1979; Johnson 1960; Stein 1961). If a particular foreign currency cannot be hedged directly, mainly because of the nonexistence of forward and/or futures markets in that currency, exchange rate risk may still be reduced with a cross-hedge. Within the meanvariance framework, the general cross hedging model is based on the hedger's objective function (see Benet 1990a, 1990b)

$$
\begin{aligned}
\min _{\beta_{i} \beta_{j}} \operatorname{var}\left(d H_{t}\right)=\operatorname{var}\left(d S_{t}\right)+ & \sum_{i} \beta_{i}^{2} \operatorname{var}\left(d F_{i, t}\right)+2 \sum_{i} \beta_{i} \operatorname{cov}\left(d S_{t}, d F_{i, t}\right) \\
& +2 \sum_{i} \sum_{j} \beta_{i} \beta_{j} \operatorname{cov}\left(d F_{i, t}, d F_{j, t}\right)
\end{aligned}
$$

subject to

$$
E\left(d H_{t}\right)=E\left(d S_{t}\right)+\sum_{i} \beta_{i} E\left(d F_{i, t}\right)
$$

where

$$
d S_{t}=\text { the difference in spot price during period } t,
$$




$$
\begin{aligned}
d F_{i, t}= & \text { the difference in the prices of the } i^{t h} \text { futures contracts during } \\
& \text { period } t, \\
d H_{t}= & \text { the target expected change in value of a portfolio invested in a } \\
& \text { fixed level of spot currency and } n \text { futures contracts, each in } \\
& \text { proportion } \beta_{\mathrm{i}} \text { during period } t, \\
\beta_{i}= & \text { the proportion of integer number of future contracts. Thus, } \beta_{i} \\
& \text { would equal the hedge ratio with } \beta_{i}<0 \text { representing a short } \\
& \text { position and } \beta_{i}>0 \text { representing a long position in futures. }
\end{aligned}
$$

Ederington (1979), Anderson and Danthine (1981), and others have shown that this approach reduces to an ordinary least squares (OLS) regression of a single spot position on single or multiple futures positions. The empirical cross-hedging regression equation is of the general form:

$$
d S_{t}=\alpha+\beta_{1} d F_{1, t}+\beta_{2} d F_{2, t}+\ldots+\beta_{n} d F_{n, t}+\varepsilon_{t}
$$

The optimal or least-risk hedge ratio, $b^{*}$, is simply obtained from the parameter estimates, $\beta_{i}$, of the above multivariate regression equation. ${ }^{3}$ The degree of hedging effectiveness, $e$, for the minimum-risk hedge is measured by the regression coefficient of determination, $R^{2}$.

The model in its empirically-testable form (equation 3 ) is used to examine the performance of single and multiple cross-hedging strategies. The specific model form adopted for this study is logarithmic; that is, the natural log of the cash and futures prices is taken first before computing the price differences. ${ }^{4}$ Since the variance and covariance terms are now expressed in returns form rather than prices, the cross-hedge ratio estimates are interpretable as elasticity measures (Benet 1990a). A "naive" out-of-sample hedging approach is

3. Disagreement arises on the best procedure to estimate the least-risk hedge ratio; namely, whether to use cash and futures price levels, price changes, or percentage changes in the analytical approach. Witt, Schroeder, and Hayenga (1987) have compared all three estimation techniques and concluded that the proper statistical method (at least theoretically) depends on the hedger's objective function and the type of hedge being considered. In the present study, the objective function of the hedger is to minimize the variance of returns. The hedge is a storage hedge. Thus, the current spot price is relevant to the hedging decision. In this case, "the price change model seems appropriate," as suggested by Witt, Schroeder, and Hayenga (1987, p. 145).

4. While the Ederington methodology is simple and easy to use, the optimal hedge parameter estimates from the OLS technique will yield unbiased results only when the data satisfies the assumptions of homoskedasticity and no serial correlation. Preliminary regressions performed on the data reveal the presence of heteroskedasticity and autocorrelation. The first problem is eliminated by taking the natural logarithm of the data. The problem of autocorrelation among residuals is corrected with an autocorrelation-corrected model. The Cochran-Orcutt technique was used ex post and ex ante. 
employed where the total sample data is divided into three subsamples. ${ }^{5}$ Least risk hedge ratios are estimated for each subsample separately, and then prior subperiod optimal hedge ratios are used to construct a hedge for the subsequent (holding) period (e.g., the hedge ratio estimated in subperiod 1 is implemented into subperiod 2, subperiod's 2 into 3$)^{6}{ }^{6}$

The hedging results obtained from ex post data are useful only to a hedger on an ex ante basis if the estimated optimal cross-hedge ratios are stable over time. In fact, intertemporal hedge ratio variability causes a general failure of the "naive" hedging approach because of structural shifts between changes in the spot and futures prices. Hedge ratio stability is particularly important for cross-hedging since the underlying structural factors of a currency used in the cross-hedge may not be well-developed. Gujarati (1978) suggested a formal stability test of the following form: ${ }^{7}$

$$
d S_{t}=\alpha+\beta_{i} \sum_{i} d F_{i, t}+\gamma_{1} \sum_{i} D_{1} d F_{i, t}+\gamma_{2} \sum_{i} D_{2} d F_{i, t}+\varepsilon_{t}
$$

where

$$
\begin{aligned}
d S_{t}= & \text { the difference in spot price during period } t, \\
d F_{i, t}= & \text { the difference in the prices of the } t^{t h} \text { futures contracts during } \\
& \text { period } t, \\
D_{1}= & 1 \text { for the period June } 1986 \text { to September } 1989, \text { and } 0 \text { otherwise, } \\
D_{2}= & 1 \text { for the period October } 1989 \text { to December 1992, and } 0 \\
& \text { otherwise. }
\end{aligned}
$$

In regression equation $4, \beta_{1}$ represents the optimal hedge ratio for the period January 1983 to May 1986. The coefficients $\gamma_{1}$ and $\gamma_{2}$ represent changes (or structural shifts) in the hedge ratio over the corresponding period. Thus, the estimated hedge ratio is expected to be stable over time if $\gamma_{1}=\gamma_{2}=0$.

The pre-specification of the subperiods in the above test is based on equal sample size. However, particular economic events that impact the foreign exchange markets or shifts in the exchange rate regimes during one of the subperiods could bias the estimated hedge ratio instability. Thus, the hedge

5. The subperiods were chosen on the basis of adequate sample size for statistical purposes using monthly data (Benet 1990a, 1990b, 1992).

6. Actual participants in futures markets probably use more sophisticated hedging strategies in establishing hedge ratios. The "naive" approach, however, offers a convenient performance benchmark for comparison purposes, (Benet 1992).

7. The construction of dummy variable tests following Gujarati (1978) allows for testing directly if and when significant structural shifts occurred in hedge ratios (Grammatikos and Saunders, 1983; Park, Lee and Lee, 1987; Benet, 1990b). 
ratio stability test is repeated with the full sample period divided into three subperiods reflecting changes in the international exchange rate regimes; that is, the first period ends just before the Plaza Agreement in September 1985, the second period before the Louvre Accord in February 1987, and the third period with the end of the study period.

Finally, simulation analysis is used to compare the effectiveness of portfolio model hedging with naive hedging rules. The simulation is run as follows. Assume a hedger who is long in futures and who has a predetermined estimation (or base) period (January 1983 to September 1989) and a hedge period (October 1989 to December 1992). These period divisions coincide with the subperiods used in the Gujarati hedge ratio stability test to make direct inferences between optimal hedge ratio stability and hedging effectiveness. Furthermore, the hedger is assumed to be continuously cross-hedged over a non-overlapping hedge length of four weeks; that is, as one hedge is lifted, another hedge with comparable characteristics is placed.

For the portfolio strategy, optimal hedge parameters over the estimation period are derived using equation 3 . These hedge ratios are then applied over the hedge period and given hedge length. For the naive strategy, the crosshedge ratios are set equal to one. Expected portfolio returns are computed under each hedging strategy. Based on this approach, hedging effectiveness is measured as the percentage reduction in the variance of returns on a hedged portfolio (optimal or naive) relative to an unhedged position. If the portfolio model cross-hedge results in risk reduction performance superior to the naive cross-hedge, the variance of the cross-hedged portfolio's returns should be minimized.

\section{Empirical Results}

Table 1 reports ex post estimates of risk minimizing OLS regression crosshedge ratios, $b^{*}$ (regression coefficient), and hedging effectiveness, $e$ (regression coefficient of determination) for six minor currencies. The five currency futures contracts most actively traded on the IMM are used to create single and multiple portfolio cross hedges. Although hedging performance varies across countries, in-sample hedging effectiveness results support the cross-hedging strategies of all minor currencies except the Hong Kong dollar. For single portfolio hedges (excluding the Hong Kong dollar), the $\mathrm{R}^{2} \mathrm{~s}$ range from .0147 for a Canadian dollar futures cross-hedge of the Singapore dollar to .7996 for the German mark futures cross-hedge of the Italian lira. The majority of cross-hedges are significantly different from the naive hedge ratio of one at the five-percent level. 
TABLE 1. Optimal Hedge Ratios and in-Sample Hedging Effectiveness for Single and Multiple Currency Futures Cross-Hedges

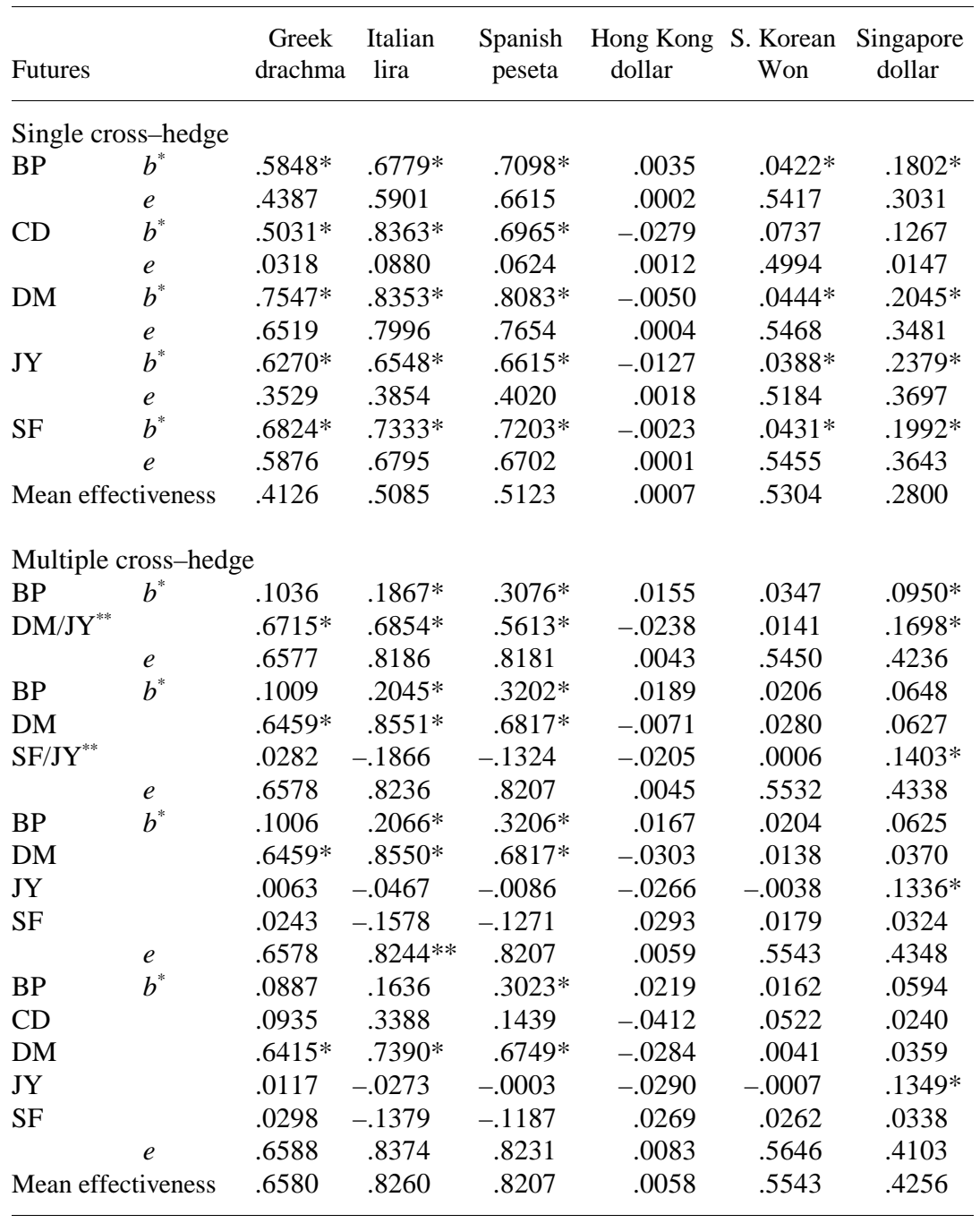

Note: Sampling period is January 1983 to December 1992. The Japanese yen futures contact is used in constructing the multiple cross-hedges for the Asian currencies. $e$ denotes in-sample hedging effectiveness; $b^{*}$ is the optimal hedge ratio; *Statistically significant from zero at the 5\% level. **Statistically significant at the 5\% level for an F-test.

Strong evidence appears to exist that the three minor European currencies (Italian lira, Spanish peseta, Greek drachma) and the South Korean won are most effectively cross-hedged with German mark futures. The degree of correlation ranges from .5468 for the Korean won to .7996 for the Italian lira. 
The Singapore dollar is most strongly correlated with Japanese yen futures with an $R^{2}$ of .3697. In-sample hedging effectiveness for the Hong Kong dollar is relatively small, suggesting that none of the currency futures contracts offer effective cross-hedges. Since currencies tend to have dominant economic influences, it is evident that the minor European currencies are linked to the mark and the minor Asian currencies to the yen. The Canadian dollar offers the least-effective cross-hedge, which is most likely caused by the close relationship between the Canadian and U.S. currencies.

Multiple portfolio cross-hedging strategies are generally more successful in reducing foreign exchange rate risk. Mean hedging effectiveness is .6546 compared with .4487 for all single portfolio hedges (excluding the Hong Kong dollar). However, portfolio size does not have a significant statistical effect on hedging performance. Based on an F-test, a two-currency futures cross-hedge is as effective in minimizing currency risk as a five-currency futures crosshedge. ${ }^{8}$ The German mark futures contract remains statistically significant at the five-percent level in all multiple cross-hedges of the minor European currencies, while Japanese yen futures are statistically significant in the multiple cross-hedges of the Singapore dollar. In some cases, the multiple portfolio cross-hedge offers only marginal improvement in hedging performance to the single portfolio cross-hedge found to be most strongly correlated with the spot currency. For example, Greek drachma risk can be reduced by 65.19 percent when cross-hedged with German mark futures alone. Yet, only a 65.88 percent risk reduction is possible with a five-currency futures cross-hedge.

In-sample hedging effectiveness presents a useful measure for examining the degree of correlation between currency spot and futures prices (percentage changes). It also offers empirical support for the cross-hedging strategies. However, out-of-sample hedging results are more useful and more realistic estimates of performance available to the real-world practitioner. Hedge ratio and (in-sample and out-of-sample) hedging effectiveness estimates for three subperiods are reported in table 2. The single and multiple cross-hedging strategies are tested using a "naive" out-of-sample approach, where prior subperiod hedge ratios are implemented into the subsequent hedge subperiod. ${ }^{9}$

8. In a general F-test, the $R^{2} \mathrm{~s}$ of the unconstrained and constrained models, adjusted for degrees of freedom, are compared. In all cases (except for the four-currency futures cross-hedge of the Italian lira), the F-values are statistically insignificant at the five-percent level. Thus, the constrained regression model can be accepted as representing the multiple cross-hedge for all minor European and Asian currencies examined.

9. For example, the $e^{\prime}=84.34$ percent $e x$ ante cross-hedging effectiveness, reported in table 2 for the German mark futures cross-hedge of the Greek drachma, is obtained by constraining the hedge ratio at $b^{*}=.6029$ (from estimation subperiod 1) for German mark futures in subperiod 2. The ex post hedging effectiveness measure, $e$, is 89.51 percent for the second subperiod. 
TABLE 2. In-Sample Versus Out-of-Sample Hedging Effectiveness for Single and Multiple Currency Futures

\begin{tabular}{|c|c|c|c|c|c|c|c|}
\hline \multirow{2}{*}{ Futures } & & \multicolumn{3}{|c|}{ Greek drachma } & \multicolumn{3}{|c|}{ Italian lira } \\
\hline & & \multirow[t]{2}{*}{ Period 1} & \multirow[t]{2}{*}{ Period 2} & \multirow[t]{2}{*}{ Period 3} & \multirow[t]{2}{*}{ Period 1} & Period 2 & \multirow[t]{2}{*}{ Period 3} \\
\hline \multicolumn{3}{|c|}{ Single cross-hedge } & & & & & \\
\hline \multirow[t]{3}{*}{$\mathrm{BP}$} & $b^{*}$ & .4210 & .6506 & .6760 & .5048 & .6619 & .8362 \\
\hline & $e$ & .1773 & .6639 & .6788 & .3980 & .5961 & .7587 \\
\hline & $e^{\prime}$ & & .5776 & 6777 & & .5559 & .7052 \\
\hline \multirow[t]{3}{*}{$\mathrm{CD}$} & $b^{*}$ & .9236 & .3428 & .2602 & .9003 & .2751 & 1.2322 \\
\hline & $e$ & .0626 & .0196 & .0100 & .0929 & .0109 & .1632 \\
\hline & $e^{\prime}$ & & -.0367 & .0090 & & -.0454 & .0647 \\
\hline \multirow[t]{3}{*}{ DM } & $b^{*}$ & .6029 & .7721 & .9186 & .7261 & .8635 & .9671 \\
\hline & $e$ & .3729 & .8951 & .9116 & .8444 & .9187 & .7381 \\
\hline & $e^{\prime}$ & & .8434 & .8884 & & .8861 & .7296 \\
\hline \multirow[t]{3}{*}{ JY } & $b^{*}$ & .5952 & .6417 & .6625 & .7693 & .6622 & .5221 \\
\hline & $e$ & .1958 & .7909 & .2768 & .5108 & .7276 & .1256 \\
\hline & $e^{\prime}$ & & .7867 & .2766 & & .7086 & .1166 \\
\hline \multirow[t]{3}{*}{ SF } & $b^{*}$ & .5625 & .6478 & .8601 & .6570 & .7169 & .8525 \\
\hline & $e$ & .3296 & .8047 & .8261 & .7017 & .8432 & .5929 \\
\hline & $e^{\prime}$ & & .7936 & .7758 & & .8272 & .5779 \\
\hline \multirow[t]{2}{*}{ Median } & $e$ & & .7909 & .6788 & & .7276 & .5929 \\
\hline & $e^{\prime}$ & & .7867 & .6777 & & .7086 & .5779 \\
\hline \multicolumn{8}{|c|}{ Multiple cross-hedge } \\
\hline $\mathrm{BP}$ & $b^{*}$ & -.0116 & .1729 & .1374 & -.0182 & .0181 & .4899 \\
\hline \multirow[t]{3}{*}{ DM } & & .6108 & .6347 & .7898 & .7387 & .8528 & .5077 \\
\hline & $e$ & .3730 & .9160 & .9217 & .8446 & .9152 & .8320 \\
\hline & $e^{\prime}$ & & .8406 & .9050 & & .8845 & .7374 \\
\hline BP & $b^{*}$ & -.0195 & .1752 & .1263 & .0039 & .0187 & .5284 \\
\hline DM & & .5745 & .5550 & .6825 & .8400 & .7842 & .8162 \\
\hline \multirow[t]{3}{*}{ SF } & & .0445 & .0707 & .1250 & -.1240 & .0624 & -.3593 \\
\hline & $e$ & .3732 & .9169 & .9241 & .8474 & .9159 & .8465 \\
\hline & $e^{\prime}$ & & .8411 & .9036 & & .8790 & .7327 \\
\hline BP & $b^{*}$ & -.0478 & .1001 & .1253 & .0221 & .0000 & .5551 \\
\hline DM & & .5751 & .5829 & .6831 & .7784 & .7909 & .7975 \\
\hline JY & & -.1259 & .1759 & .0076 & .0805 & .0442 & -.2574 \\
\hline \multirow[t]{3}{*}{ SF } & & .1393 & -.0497 & .1221 & -.0398 & .0320 & -.2636 \\
\hline & $e$ & .3758 & .9284 & .9242 & .8513 & .9165 & .8670 \\
\hline & $e^{\prime}$ & & .7764 & .8586 & & .8994 & .7170 \\
\hline BP & $b^{*}$ & -.0810 & .0935 & .1275 & .0136 & .0185 & .4533 \\
\hline $\mathrm{CD}$ & & .2768 & .0602 & -.0149 & .1502 & .0712 & .7015 \\
\hline DM & & .5996 & .5792 & .6850 & .8528 & .7694 & .7067 \\
\hline JY & & -.1009 & .1718 & .0057 & .1366 & .0746 & -.1682 \\
\hline \multirow[t]{3}{*}{ SF } & & .0980 & -.0405 & .1193 & -.2392 & -.0251 & -.1315 \\
\hline & $e$ & .3798 & .9289 & .9242 & .8531 & .9049 & .9116 \\
\hline & $e^{\prime}$ & & .7740 & .8590 & & .8871 & .7261 \\
\hline \multirow[t]{2}{*}{ Median } & $e$ & & .9227 & .9242 & & .9156 & .8568 \\
\hline & $e^{\prime}$ & & .8085 & .8813 & & .8858 & .7294 \\
\hline
\end{tabular}

(Continued) 
TABLE 2. (Continued)

\begin{tabular}{|c|c|c|c|c|c|c|c|}
\hline \multirow{2}{*}{ Futures } & & \multicolumn{3}{|c|}{ Spanish peseta } & \multicolumn{3}{|c|}{ Hong-Kong dollar } \\
\hline & & \multirow[t]{2}{*}{ Period 1} & \multirow[t]{2}{*}{ Period 2} & \multirow[t]{2}{*}{ Period 3} & \multirow[t]{2}{*}{ Period 1} & \multirow[t]{2}{*}{ Period 2} & \multirow[t]{2}{*}{ Period 3} \\
\hline \multicolumn{2}{|c|}{ Single cross-hedge } & & & & & & \\
\hline \multirow[t]{3}{*}{$\mathrm{BP}$} & $b^{*}$ & .5746 & .7288 & .8138 & .0159 & .0006 & -.0065 \\
\hline & $e$ & .4964 & .6894 & .8017 & .0014 & .0003 & .0345 \\
\hline & $e^{\prime}$ & & .6542 & .7926 & & -.2204 & -.0076 \\
\hline \multirow[t]{3}{*}{$\mathrm{CD}$} & $b^{*}$ & .8536 & .3655 & .8064 & -.2230 & -.0009 & .0097 \\
\hline & $e$ & .0804 & .0185 & .0780 & .0206 & .0001 & .0078 \\
\hline & $e^{\prime}$ & & -.0145 & .0547 & & -4.9187 & -.0015 \\
\hline \multirow[t]{3}{*}{$\mathrm{DM}$} & $b^{*}$ & .6988 & .7848 & .9615 & -.0162 & .0073 & -.0104 \\
\hline & $e$ & .7530 & .7549 & .8138 & .0015 & .0474 & .0656 \\
\hline & $e^{\prime}$ & & .7432 & .7863 & & -.4478 & -.1237 \\
\hline \multirow[t]{3}{*}{ JY } & $b^{*}$ & .6845 & .6639 & .6543 & -.0428 & .0029 & .0021 \\
\hline & $e$ & .3893 & .7031 & .2200 & .0057 & .0098 & .0016 \\
\hline & $e^{\prime}$ & & .7024 & .2200 & & -2.3888 & .0014 \\
\hline \multirow[t]{3}{*}{ SF } & $b^{*}$ & .6627 & .6539 & .8810 & -.0119 & .0053 & -.0059 \\
\hline & $e$ & .6873 & .6478 & .7063 & .0008 & .0326 & .0217 \\
\hline & $e^{\prime}$ & & .6561 & .6593 & & -.3087 & -.0564 \\
\hline \multirow[t]{2}{*}{ Median } & $e$ & & 6894 & .7063 & & .0098 & .0217 \\
\hline & $e^{\prime}$ & & .6561 & .6593 & & -.4478 & -.0076 \\
\hline \multicolumn{8}{|c|}{ Multiple cross-hedge } \\
\hline $\mathrm{BP}$ & $b^{*}$ & .1560 & .3358 & .4386 & .0395 & -.0061 & -.0096 \\
\hline \multirow[t]{3}{*}{$\mathrm{DM}$} & & .5910 & .5141 & .5503 & -.0677 & .0074 & .0096 \\
\hline & $e$ & .7717 & .8147 & .8978 & .0126 & .0214 & .0585 \\
\hline & $e^{\prime}$ & & .7855 & .8777 & & -2.6072 & .0503 \\
\hline $\mathrm{BP}$ & $b^{*}$ & .1535 & .3125 & .4475 & .0488 & -.0111 & -.0002 \\
\hline $\mathrm{DM}$ & & .5793 & .8164 & .6361 & -.0208 & .0220 & -.0153 \\
\hline \multirow[t]{3}{*}{$\mathrm{SF}$} & & .0143 & -.2646 & -.0999 & -.0520 & -.0058 & .0127 \\
\hline & $e$ & .7717 & .8219 & .8990 & .0133 & .1178 & .1068 \\
\hline & $e^{\prime}$ & & .7842 & .8768 & & -2.4421 & -.2607 \\
\hline BP & $b^{*}$ & .1320 & .2278 & .4577 & .0412 & -.0121 & -.0017 \\
\hline $\mathrm{DM}$ & & .5797 & .8141 & .6303 & -.0413 & .0309 & -.0334 \\
\hline JY & & -.0953 & .2205 & -.0795 & -.0657 & -.0035 & .0099 \\
\hline \multirow[t]{3}{*}{ SF } & & .0861 & -.3994 & -.0704 & .0354 & -.0095 & .0218 \\
\hline & $e$ & .7739 & .8350 & .9011 & .0139 & .1248 & .1458 \\
\hline & $e^{\prime}$ & & .7505 & .8014 & & -2.4843 & -.3025 \\
\hline $\mathrm{BP}$ & $b^{*}$ & .1589 & .2264 & .4033 & .0875 & -.0122 & -.0055 \\
\hline $\mathrm{CD}$ & & -.2240 & .0275 & .3753 & -.3866 & .0006 & .0259 \\
\hline $\mathrm{DM}$ & & .5599 & .8106 & .5817 & -.0756 & .0308 & -.0367 \\
\hline JY & & -.1155 & .2182 & -.0318 & -.1006 & -.0036 & .0132 \\
\hline \multirow[t]{3}{*}{ SF } & & .1196 & -.3937 & .0003 & .0932 & -.0094 & .0267 \\
\hline & $e$ & .7778 & .8351 & .9154 & .0577 & .1248 & .1920 \\
\hline & $e^{\prime}$ & & .7323 & .8048 & & -18.6229 & -.2994 \\
\hline \multirow[t]{2}{*}{ Median } & $e$ & & .8285 & .9001 & & .1213 & .1263 \\
\hline & $e^{\prime}$ & & .7674 & .8408 & & -2.5458 & -.2801 \\
\hline
\end{tabular}

(Continued) 
TABLE 2. (Continued)

\begin{tabular}{|c|c|c|c|c|c|c|c|}
\hline \multirow{2}{*}{ Futures } & & \multicolumn{3}{|c|}{ South Korean won } & \multicolumn{3}{|c|}{ Singapore dollar } \\
\hline & & Period 1 & Period 2 & Period 3 & Period 1 & Period 2 & Period 3 \\
\hline \multicolumn{8}{|c|}{ Single cross-hedge } \\
\hline \multirow[t]{3}{*}{$\mathrm{BP}$} & $b^{*}$ & .0697 & .0520 & -.0203 & .1490 & .1647 & .2124 \\
\hline & $e$ & .3032 & .3614 & .3221 & .1544 & .4897 & .4688 \\
\hline & $e^{\prime}$ & & .0483 & -.5243 & & .4624 & .4451 \\
\hline \multirow[t]{3}{*}{$\mathrm{CD}$} & $b^{*}$ & .1690 & .1066 & .0329 & .1612 & .1756 & .0225 \\
\hline & $e$ & .1534 & .0342 & .3036 & .0133 & .0511 & .0005 \\
\hline & $e^{\prime}$ & & .0214 & -.1070 & & .0508 & -.0236 \\
\hline \multirow[t]{3}{*}{$\mathrm{DM}$} & $b^{*}$ & .0707 & .0430 & -.0246 & .1842 & .1652 & .2625 \\
\hline & $e$ & .3758 & .3261 & .3274 & .2420 & .4083 & .5209 \\
\hline & $e^{\prime}$ & & -.1072 & -.2544 & & .4028 & .4492 \\
\hline \multirow[t]{3}{*}{ JY } & $b^{*}$ & .0869 & .0298 & -.0121 & .3348 & .1501 & .3477 \\
\hline & $e$ & .2740 & .3066 & .2971 & .4307 & .4304 & .5334 \\
\hline & $e^{\prime}$ & & -.1287 & .0089 & & -.2974 & .3611 \\
\hline \multirow[t]{3}{*}{ SF } & $b^{*}$ & .0642 & .0362 & -.0194 & .2025 & .1512 & .2498 \\
\hline & $e$ & .3118 & .3169 & .3115 & .2968 & .4379 & .4874 \\
\hline & $e^{\prime}$ & & -.1308 & -.1933 & & .3875 & .4114 \\
\hline \multirow[t]{2}{*}{ Median } & $e$ & & .3169 & .3115 & & .4304 & .4874 \\
\hline & $e^{\prime}$ & & -.1072 & -.1933 & & .3875 & .4114 \\
\hline \multicolumn{8}{|c|}{ Multiple cross-hedge } \\
\hline $\mathrm{BP}$ & $b^{*}$ & .0526 & .0693 & -.0247 & .0414 & .1146 & .1313 \\
\hline \multirow[t]{3}{*}{ JY } & & .0542 & -.0192 & .0100 & .3087 & .0655 & .2456 \\
\hline & $e$ & .3890 & .3672 & .3237 & .4400 & .4994 & .6665 \\
\hline & $e^{\prime}$ & & -.0581 & -.7633 & & -.2883 & .4999 \\
\hline $\mathrm{BP}$ & $b^{*}$ & .0346 & .0625 & -.0118 & .0684 & .1062 & .0568 \\
\hline $\mathrm{DM}$ & & .0340 & .0278 & -.0186 & -.0608 & .0368 & .1213 \\
\hline \multirow[t]{3}{*}{ JY } & & .0275 & -.0350 & .0113 & .3545 & .0434 & .2207 \\
\hline & $e$ & .4132 & .3727 & .3309 & .4471 & .5039 & .7046 \\
\hline & $e^{\prime}$ & & -.0531 & -.9477 & & -.4585 & .5156 \\
\hline $\mathrm{BP}$ & $b^{*}$ & .0473 & .0630 & -.0110 & .0727 & .1219 & .0592 \\
\hline DM & & .0917 & .0220 & -.0345 & -.0492 & -.0982 & .1509 \\
\hline JY & & .0615 & -.0364 & .0060 & .3623 & .0083 & .2253 \\
\hline \multirow[t]{3}{*}{ SF } & & -.0872 & .0067 & .0201 & -.0200 & .1445 & -.0358 \\
\hline & $e$ & .4487 & .3729 & .3346 & .4474 & .5306 & .7059 \\
\hline & $e^{\prime}$ & & -.0643 & -.9618 & & -.4896 & .4620 \\
\hline $\mathrm{BP}$ & $b^{*}$ & .0387 & .0635 & -.0625 & .0821 & .1151 & .0578 \\
\hline $\mathrm{CD}$ & & .0718 & .0216 & .0550 & -.0787 & .1308 & .0098 \\
\hline DM & & .0906 & .0175 & -.0027 & -.0562 & -.1148 & .1496 \\
\hline JY & & .0713 & -.0382 & .0709 & .3552 & -.0025 & .2265 \\
\hline \multirow[t]{3}{*}{ SF } & & -.0942 & .0119 & .0034 & -.0082 & .1716 & -.0339 \\
\hline & $e$ & .4664 & .3750 & .2252 & .4496 & .5570 & .7060 \\
\hline & $e^{\prime}$ & & -.0681 & -.9964 & & -.5263 & -2.1686 \\
\hline \multirow{2}{*}{ Median } & $e$ & & .3728 & .3273 & & .5173 & .7053 \\
\hline & $e^{\prime}$ & & -.0612 & -.9548 & & -.4741 & .4810 \\
\hline
\end{tabular}

Note: $\quad e$ denotes ex post hedging effectiveness, $e^{\prime}$ denotes $e x$ ante hedging effectiveness, and $b^{*}$ denotes optimal hedge ratio. Sampling period is January 1983 to December 1992. 
The results reported in table 2 illustrate a divergence between ex post (e) and $e x$ ante $\left(e^{\prime}\right)$ hedging effectiveness. Ex post single and multiple crosshedging strategies successfully reduce foreign exchange rate risk. Single portfolio strategies are more variable in ex post performance across currency futures hedges. But when combined in a portfolio, the variability in ex post hedging effectiveness is significantly reduced. Thus, the diversification benefits of multiple portfolio cross-hedges are evident ex post. However, such ex post results overstate true hedging performance, since optimal hedge ratios are unknown at the beginning of the holding period.

Exante performance $\left(e^{\prime}\right)$, as shown in table 2, is lower for all cross-hedging strategies. ${ }^{10}$ One of the more dramatic discrepancies between $e$ and $e$ ' can be found for Singapore in the third subperiod. A five-currency futures crosshedge is 70.60 percent effective using in-sample measures, while foreign exchange rate risk is actually increased by 216.86 percent when measured on an $e x$ ante basis. The difference between ex post and ex ante hedging results is most pronounced for the single and multiple cross-hedges of the minor Asian currencies. According to ex ante estimates, exchange rate risk is actually increased (negative hedging effectiveness measures) relative to an unhedged position. The "drop" from $e$ to $e$ ', however, is less dramatic for the single and multiple cross-hedges of the Greek drachma, Spanish peseta, and Italian lira.

The discrepancy between ex post and ex ante hedging effectiveness measures appears to be caused by variability in the optimal hedge ratios. This problem is apparent in table 2, where single and multiple cross-hedge ratios fluctuate across subperiods. Hedge ratio instability, which causes a general failure of the "naive" out-of-sample hedging approach, is formally tested using Gujarati's (1978) dummy variable test. The results are presented in table 3.

For all single and multiple portfolio hedges tested, the dummy variable equation (equation 4) produces a better fit than the "standard" portfolio hedge model (equation 3). However, not all dummy coefficients are significantly different from zero at the five-percent level. Hedge ratio instability is present for the single and multiple portfolio cross-hedges of the Greek drachma, Italian lira, Spanish peseta, and South Korean won across holding periods. The relationship between the single and multiple futures prices and the spot prices of the Singapore dollar and Hong Kong dollar appear fairly stable over time. Similar results are obtained for all currencies except the Hong Kong dollar when the subperiods are synchronized with changes in the international exchange rate regimes. ${ }^{11}$

10. These results are consistent with those reported by Eaker and Grant (1987) and Benet (1990a, 1990b, 1992), who examined both commodity and currency cross-hedges.

11. Results are available from the author upon request. 
TABLE 3. Hedge Ratio Stability Test For Single and Multiple Currency Futures Cross-Hedges

\begin{tabular}{|c|c|c|c|c|c|c|}
\hline \multirow[b]{2}{*}{ Currencies } & \multicolumn{3}{|c|}{ Greek drachma } & \multicolumn{3}{|c|}{ Italian lira } \\
\hline & $\gamma_{1}$ & $1 / 2$ & $R^{2}$ & $\gamma_{1}$ & $\gamma_{2}$ & $R^{2}$ \\
\hline \multicolumn{7}{|c|}{ Single cross-hedge } \\
\hline \multirow[t]{2}{*}{$\mathrm{BP}$} & .2273 & .2504 & .4551 & .1598 & .3304 & .6149 \\
\hline & $(1.47)$ & $(1.73)$ & & $(1.23)$ & $(2.72)^{*}$ & \\
\hline \multirow[t]{2}{*}{$\mathrm{CD}$} & -.5970 & -.7554 & .0435 & -.6129 & .3052 & .1070 \\
\hline & $(-.87)$ & $(-1.16)$ & & $(-.93)$ & $(.49)$ & \\
\hline \multirow[t]{2}{*}{$\mathrm{DM}$} & .1796 & .3209 & .6723 & .1172 & .2371 & .8106 \\
\hline & $(1.49)$ & $(2.66) *$ & & $(1.28)$ & $(2.58) *$ & \\
\hline \multirow[t]{2}{*}{ JY } & .1215 & .1364 & .3558 & -.0505 & -.2014 & .3904 \\
\hline & $(.65)$ & $(.61)$ & & $(-.28)$ & $(-.93)$ & \\
\hline \multirow[t]{2}{*}{ SF } & .9670 & .3012 & .6062 & .0581 & .1933 & .6872 \\
\hline & $(.78)$ & $(2.30)^{*}$ & & $(.53)$ & $(1.66)$ & \\
\hline \multicolumn{7}{|c|}{ Multiple cross-hedge } \\
\hline \multirow[t]{2}{*}{$\mathrm{BP}$} & .1347 & .1328 & & .0597 & .5066 & \\
\hline & $(.74)$ & $(.78)$ & & $(.49)$ & $(4.41)^{*}$ & \\
\hline \multirow[t]{2}{*}{$\mathrm{DM}$} & .0715 & .1981 & .6778 & .0686 & -.2295 & .8543 \\
\hline & $(.39)$ & $(1.06)$ & & $(.56)$ & $(-1.83)$ & \\
\hline \multirow[t]{2}{*}{$\mathrm{BP}$} & .1427 & .1302 & & .0376 & .5172 & \\
\hline & $(.75)$ & $(.72)$ & & $(.30)$ & $(4.38) *$ & \\
\hline \multirow[t]{2}{*}{$\mathrm{DM}$} & .1757 & .1327 & & -.0185 & -.0224 & \\
\hline & $(.42)$ & $(.39)$ & & $(-.07)$ & $(-.10)$ & \\
\hline \multirow[t]{2}{*}{ SF } & -.1078 & .0743 & .6788 & .1108 & -.2362 & .8616 \\
\hline & $(-.29)$ & $(.22)$ & & $(.45)$ & $(-1.05)$ & \\
\hline \multirow[t]{2}{*}{$\mathrm{BP}$} & .1087 & .1803 & & -.0142 & .5298 & \\
\hline & $(.52)$ & $(.96)$ & & $(-.11)$ & $(4.42)^{*}$ & \\
\hline \multirow[t]{2}{*}{$\mathrm{DM}$} & .1523 & .1249 & & -.0207 & -.0328 & \\
\hline & $(.37)$ & $(.36)$ & & $(-.08)$ & $(-.15)$ & \\
\hline \multirow[t]{2}{*}{ JY } & .4333 & .2177 & & .0253 & -.3249 & \\
\hline & $(1.58)$ & $(.90)$ & & $(.14)$ & $(-2.10)^{*}$ & \\
\hline \multirow[t]{2}{*}{ SF } & -.3919 & -.0840 & .6862 & .1063 & -.0908 & .8718 \\
\hline & $(-.94)$ & $(-.22)$ & & $(.40)$ & $(-.38)$ & \\
\hline \multirow[t]{2}{*}{$\mathrm{BP}$} & .1427 & .2214 & & .0089 & .4478 & \\
\hline & $(.66)$ & (1.12) & & $(.07)$ & $(3.84)^{*}$ & \\
\hline \multirow[t]{2}{*}{$\mathrm{CD}$} & -.1877 & -.3553 & & -.0980 & .4974 & \\
\hline & $(-.40)$ & $(-.78)$ & & $(-.36)$ & $(1.86)$ & \\
\hline \multirow[t]{2}{*}{$\mathrm{DM}$} & .0922 & .0957 & & -.0635 & -.1334 & \\
\hline & $(.22)$ & $(.27)$ & & $(-.26)$ & $(-.65)$ & \\
\hline \multirow[t]{2}{*}{ JY } & .3719 & .1696 & & -.0069 & -.2534 & \\
\hline & $(1.32)$ & $(.67)$ & & $(-.04)$ & $(-1.71)$ & \\
\hline \multirow[t]{2}{*}{ SF } & -.2913 & -.0257 & .6896 & .1675 & .0683 & .8928 \\
\hline & $(-.67)$ & $(-.07)$ & & $(.66)$ & $(.30)$ & \\
\hline
\end{tabular}


TABLE 3. (Continued)

\begin{tabular}{|c|c|c|c|c|c|c|}
\hline \multirow[b]{2}{*}{ Currencies } & \multicolumn{3}{|c|}{ Spanish peseta } & \multicolumn{3}{|c|}{ Hong-Kong dollar } \\
\hline & $\gamma_{1}$ & $\gamma / 2$ & $R^{2}$ & $\gamma_{1}$ & $\gamma_{2}$ & $R^{2}$ \\
\hline \multicolumn{7}{|c|}{ Single cross-hedge } \\
\hline \multirow[t]{2}{*}{$\mathrm{BP}$} & .1501 & .2362 & .6745 & -.0146 & -.0253 & .0020 \\
\hline & $(1.27)$ & $(2.14)^{*}$ & & $(-.25)$ & $(-.46)$ & \\
\hline \multirow[t]{2}{*}{$\mathrm{CD}$} & -.4997 & -.1172 & .0677 & .1820 & .1333 & .0091 \\
\hline & $(-.75)$ & $(-.18)$ & & $(.93)$ & $(.72)$ & \\
\hline \multirow[t]{2}{*}{ DM } & .0969 & .2639 & .7794 & .0320 & .0128 & .0029 \\
\hline & $(.99)$ & $(2.69)^{*}$ & & $(.54)$ & $(.22)$ & \\
\hline \multirow[t]{2}{*}{ JY } & .0464 & .0288 & .4024 & .0749 & .0746 & .0146 \\
\hline & $(.26)$ & $(.14)$ & & $(1.15)$ & $(.96)$ & \\
\hline \multirow[t]{2}{*}{ SF } & -.0114 & .2194 & .6838 & .0226 & .0105 & .0015 \\
\hline & $(-.10)$ & $(1.89)$ & & $(.41)$ & $(.18)$ & \\
\hline \multicolumn{7}{|c|}{ Multiple cross-hedge } \\
\hline \multirow[t]{2}{*}{$\mathrm{BP}$} & .1425 & .2707 & & -.0628 & -.0645 & \\
\hline & $(1.09)$ & $(2.23)^{*}$ & & $(-.72)$ & $(-1.03)$ & \\
\hline \multirow[t]{2}{*}{$\mathrm{DM}$} & -.0377 & -.0269 & .8330 & .1134 & .1149 & .0267 \\
\hline & $(-.29)$ & $(-.20)$ & & $(1.28)$ & $(1.29)$ & \\
\hline \multirow[t]{2}{*}{ BP } & .1420 & .2824 & & -.0676 & -.0611 & \\
\hline & $(1.06)$ & $(2.23)^{*}$ & & $(-.70)$ & $(-.71)$ & \\
\hline \multirow[t]{2}{*}{ DM } & .2944 & .0751 & & .0247 & -.0063 & \\
\hline & $(1.01)$ & $(.31)$ & & $(.20)$ & $(-.06)$ & \\
\hline \multirow[t]{2}{*}{ SF } & -.3087 & -.1189 & .8367 & .0985 & .1176 & .0275 \\
\hline & $(-1.17)$ & $(-.49)$ & & $(.82)$ & $(1.10)$ & \\
\hline \multirow[t]{2}{*}{ BP } & .0931 & .3301 & & -.0513 & -.0433 & \\
\hline & $(.63)$ & $(2.52)^{*}$ & & $(-.49)$ & $(-.47)$ & \\
\hline \multirow[t]{2}{*}{ DM } & .2732 & .0649 & & .0998 & .0303 & \\
\hline & $(.94)$ & $(.27)$ & & $(.49)$ & $(.18)$ & \\
\hline \multirow[t]{2}{*}{ JY } & .3900 & .0801 & & .1347 & .1455 & \\
\hline & $(2.04)^{*}$ & $(.47)$ & & $(.99)$ & $(1.21)$ & \\
\hline \multirow[t]{2}{*}{ SF } & -.5600 & -.2075 & .8439 & -.1124 & -.0691 & .0314 \\
\hline & $(-1.92)$ & $(-.79)$ & & $(-.54)$ & $(-.37)$ & \\
\hline \multirow[t]{2}{*}{ BP } & .0729 & .2549 & & -.0908 & -.0839 & \\
\hline & $(.49)$ & (1.87) & & $(-.85)$ & $(-.86)$ & \\
\hline \multirow[t]{2}{*}{$\mathrm{CD}$} & .2265 & .5288 & & .3515 & .3339 & \\
\hline & $(.71)$ & (1.69) & & (1.54) & (1.50) & \\
\hline \multirow[t]{2}{*}{ DM } & .2765 & .0385 & & .1281 & .0610 & \\
\hline & $(.95)$ & $(.16)$ & & $(.62)$ & $(.35)$ & \\
\hline \multirow[t]{2}{*}{ JY } & .4055 & .1507 & & .1718 & .1866 & \\
\hline & $(2.09)^{*}$ & $(.87)$ & & (1.24) & $(1.51)$ & \\
\hline \multirow[t]{2}{*}{ SF } & -.5740 & -.1708 & .8503 & -.1639 & -.1233 & .0611 \\
\hline & $(-1.93)$ & $(-.64)$ & & $(-.77)$ & $(-.65)$ & \\
\hline
\end{tabular}


TABLE 3. (Continued)

\begin{tabular}{|c|c|c|c|c|c|c|}
\hline \multirow[b]{2}{*}{ Currencies } & \multicolumn{3}{|c|}{ South Korean won } & \multicolumn{3}{|c|}{ Singapore dollar } \\
\hline & $\gamma_{1}$ & $\gamma / 2$ & $R^{2}$ & $\gamma_{1}$ & $\gamma_{2}$ & $R^{2}$ \\
\hline \multicolumn{7}{|c|}{ Single cross-hedge } \\
\hline \multirow[t]{2}{*}{$\mathrm{BP}$} & -.0202 & -.0916 & .5976 & .0241 & .0589 & .3089 \\
\hline & $(-.85)$ & $(-3.89)^{*}$ & & $(.37)$ & $(.97)$ & \\
\hline \multirow[t]{2}{*}{$\mathrm{CD}$} & -.1834 & -.1676 & .5219 & -.0461 & -.2432 & .0252 \\
\hline & $(-2.16)^{*}$ & $(-2.00)^{*}$ & & $(-.18)$ & $(-1.00)$ & \\
\hline \multirow[t]{2}{*}{$\mathrm{DM}$} & -.0224 & -.0973 & .5999 & -.0114 & .0875 & .3637 \\
\hline & $(-.96)$ & $(-3.87)^{*}$ & & $(-.18)$ & $(1.40)$ & \\
\hline \multirow[t]{2}{*}{ JY } & -.0539 & -.1073 & .5536 & -.1345 & .0668 & .4190 \\
\hline & $(-1.83)$ & $(-3.01)^{*}$ & & $(-2.05)^{*}$ & $(.85)$ & \\
\hline \multirow[t]{2}{*}{ SF } & -.0239 & -.0864 & .5834 & -.0464 & .0534 & .3792 \\
\hline & $(-1.04)$ & $(-3.22)^{*}$ & & $(-.81)$ & $(.88)$ & \\
\hline \multicolumn{7}{|c|}{ Multiple cross-hedge } \\
\hline \multirow[t]{2}{*}{$\mathrm{BP}$} & .0042 & -.0726 & & .0427 & .0588 & \\
\hline & $(.12)$ & $(-2.65)^{*}$ & & $(.51)$ & $(.97)$ & \\
\hline \multirow[t]{2}{*}{ JY } & -.0601 & -.0577 & .6123 & -.1734 & .0119 & .4787 \\
\hline & $(-1.66)$ & $(-1.48)$ & & $(-2.03)^{*}$ & $(.14)$ & \\
\hline \multirow[t]{2}{*}{$\mathrm{BP}$} & .0110 & -.0390 & & .0247 & -.0363 & \\
\hline & $(.29)$ & $(-1.02)$ & & $(.27)$ & $(-.45)$ & \\
\hline \multirow[t]{2}{*}{ DM } & .0159 & -.0580 & & .0626 & .1621 & \\
\hline & $(.32)$ & $(-1.29)$ & & $(.54)$ & (1.58) & \\
\hline \multirow[t]{2}{*}{ JY } & -.0638 & -.0287 & .6240 & -.2144 & -.0341 & .4991 \\
\hline & $(-1.31)$ & $(-.63)$ & & $(-1.89)$ & $(-.34)$ & \\
\hline \multirow[t]{2}{*}{ BP } & .0021 & -.0496 & & .0537 & -.0149 & \\
\hline & $(.05)$ & $(-1.27)$ & & $(.55)$ & $(-.17)$ & \\
\hline \multirow[t]{2}{*}{ DM } & -.0519 & -.1324 & & .0040 & .2448 & \\
\hline & $(-.62)$ & $(-1.85)$ & & $(.02)$ & (1.53) & \\
\hline \multirow[t]{2}{*}{ JY } & -.0989 & -.0669 & & -.2122 & .0005 & \\
\hline & $(-1.77)$ & $(-1.27)$ & & $(-1.66)$ & $(.00)$ & \\
\hline \multirow[t]{2}{*}{ SF } & .0958 & .1087 & .6315 & .0333 & -.1250 & .5044 \\
\hline & (1.13) & (1.37) & & $(.17)$ & $(-.71)$ & \\
\hline \multirow[t]{2}{*}{$\mathrm{BP}$} & .0090 & -.0498 & & .0501 & -.0116 & \\
\hline & $(.22)$ & $(-1.23)$ & & $(.50)$ & $(-.13)$ & \\
\hline \multirow[t]{2}{*}{$\mathrm{CD}$} & -.0458 & -.0046 & & .1438 & -.0422 & \\
\hline & $(-.50)$ & $(-.05)$ & & $(.67)$ & $(-.20)$ & \\
\hline \multirow[t]{2}{*}{ DM } & -.0569 & -.1513 & & -.0282 & .2457 & \\
\hline & $(-.67)$ & $(-2.06)^{*}$ & & $(-.14)$ & (1.51) & \\
\hline \multirow[t]{2}{*}{ JY } & -.1110 & -.0739 & & -.2375 & -.0091 & \\
\hline & $(-1.93)$ & $(-1.36)$ & & $(-1.81)$ & $(-.08)$ & \\
\hline \multirow[t]{2}{*}{ SF } & .1111 & .1466 & .6393 & .0833 & -.1199 & .5128 \\
\hline & $(1.27)$ & $(1.74)$ & & $(.41)$ & $(-.66)$ & \\
\hline
\end{tabular}

Note: The residuals have been corrected for autocorrelation. Parenthesis include the tvalues for the estimates. *Statistically significant at the 5\% level. Sampling period is January 1983 to December 1992. 
TABLE 4. Simulation Results of Estimated Hedge Ratios and In-Sample Hedging Effectiveness for Single and Multiple Currency Futures Cross-Hedges

\begin{tabular}{|c|c|c|c|c|c|c|c|}
\hline Futures & & $\begin{array}{c}\text { Greek } \\
\text { drachma }\end{array}$ & $\begin{array}{c}\text { Italian } \\
\text { lira }\end{array}$ & $\begin{array}{c}\text { Spanish } \\
\text { peseta }\end{array}$ & $\begin{array}{l}\text { Hong Kong } \\
\text { dollar }\end{array}$ & $\begin{array}{l}\text { S. Korean } \\
\text { Won }\end{array}$ & $\begin{array}{c}\text { Singapore } \\
\text { dollar }\end{array}$ \\
\hline \multicolumn{8}{|c|}{ Single cross-hedge } \\
\hline \multirow[t]{2}{*}{ BP } & HR & .7993 & .7932 & .8595 & .1059 & .1191 & .2578 \\
\hline & $\mathrm{HE}$ & .5986 & .7040 & .7390 & .3173 & .4855 & .5566 \\
\hline \multirow[t]{2}{*}{$\mathrm{CD}$} & HR & .7225 & .6321 & .6830 & -.0231 & .1084 & .2372 \\
\hline & $\mathrm{HE}$ & .8060 & .7917 & .8172 & .2425 & .7335 & .7245 \\
\hline \multirow[t]{2}{*}{$\mathrm{DM}$} & HR & .6972 & .8238 & .7620 & -.0191 & .0681 & .1850 \\
\hline & $\mathrm{HE}$ & .9052 & .9879 & .9585 & .0962 & .6472 & .7994 \\
\hline \multirow[t]{2}{*}{ JY } & HR & .7344 & .7753 & .7563 & .0256 & .0784 & .2506 \\
\hline & HE & .6107 & .7779 & .7275 & .0868 & .2974 & .5977 \\
\hline \multirow[t]{2}{*}{$\mathrm{SF}$} & HR & .5797 & .6671 & .6301 & -.0131 & .0510 & .1664 \\
\hline & $\mathrm{HE}$ & .9961 & .9990 & .9978 & .4217 & .9750 & .9921 \\
\hline \multicolumn{8}{|c|}{ Multiple cross-hedge } \\
\hline $\mathrm{BP}$ & HR & .3135 & .0925 & .3693 & .1246 & .1103 & .1520 \\
\hline \multirow[t]{2}{*}{$\mathrm{DM} / \mathrm{JY} * *$} & & .6174 & .8182 & .5630 & -.0042 & .0297 & .2015 \\
\hline & $\mathrm{HE}$ & .9049 & .9888 & .9618 & .3797 & .5070 & .6369 \\
\hline $\mathrm{BP}$ & HR & .3218 & .0939 & .3878 & .1315 & .0935 & .1490 \\
\hline $\mathrm{DM}$ & & .5880 & .7979 & .6626 & -.0040 & .0434 & .0222 \\
\hline \multirow[t]{2}{*}{$\mathrm{SF} / \mathrm{JY} * *$} & & -.0004 & .0100 & -.1263 & -.0112 & -.0006 & .1792 \\
\hline & $\mathrm{HE}$ & .8989 & .9883 & .9893 & .4980 & .6885 & .6903 \\
\hline $\mathrm{BP}$ & HR & .3097 & .0876 & .3792 & .1784 & .0975 & .1490 \\
\hline $\mathrm{DM}$ & & .5873 & .7945 & .6611 & -.0378 & .0566 & -.0411 \\
\hline JY & & .1161 & .0976 & .1033 & -.0417 & -.0091 & .1349 \\
\hline \multirow[t]{2}{*}{ SF } & & -.0703 & -.0557 & -.1912 & .0214 & -.0239 & .0698 \\
\hline & $\mathrm{HE}$ & .9411 & .9915 & .9944 & .7247 & .9446 & .9749 \\
\hline $\mathrm{BP}$ & HR & .2653 & .0579 & .3651 & .1800 & .0929 & .1310 \\
\hline $\mathrm{CD}$ & & .3045 & .1707 & .0864 & -.0365 & .0335 & .1235 \\
\hline $\mathrm{DM}$ & & .5829 & .8049 & .6585 & -.0404 & .0537 & -.0428 \\
\hline JY & & .1226 & .0986 & .1018 & -.0504 & -.0090 & .1375 \\
\hline \multirow[t]{2}{*}{$\mathrm{SF}$} & & -.0729 & -.0574 & -.1919 & .0220 & -.0237 & .0688 \\
\hline & $\mathrm{HE}$ & .9517 & .9929 & .9952 & .7900 & .9498 & .9806 \\
\hline
\end{tabular}

Note: Estimation period is January 1983 to December 1992. The Japanese yen futures contact is used in constructing the multiple cross-hedges for Asian currencies. $\mathrm{HR}=$ estimated hedge ratio, $\mathrm{HE}=\mathrm{in}$-sample hedging effectiveness.

Instability of least-risk hedge ratios raises the concern over the usefulness and reliability of the portfolio model cross-hedge to reduce exchange rate risk. The hedging performance of the portfolio strategy is examined by creating a portfolio in which single and multiple optimal hedge ratios estimated over the forecast period are used to cross-hedge the spot positions of the minor 
currencies over the hedging period. Results for the single and multiple crosshedges are compared with the naive hedge strategy in which the spot position is matched by an equal but opposite futures position; that is, the hedge ratio is maintained at one $(b=1)$. Table 4 presents the simulation results of the insample hedging performance for the portfolio strategy and naive hedge rule.

TABLE 5. Portfolio Variance of Returns For Unhedged, Naively Hedged, and Portfolio Model Hedged Strategy

\begin{tabular}{|c|c|c|c|c|c|c|c|}
\hline \multicolumn{2}{|l|}{ Futures } & $\begin{array}{c}\text { Greek } \\
\text { drachma }\end{array}$ & $\begin{array}{l}\text { Italian } \\
\text { lira }\end{array}$ & $\begin{array}{c}\text { Spanish } \\
\text { peseta }\end{array}$ & $\begin{array}{l}\text { Hong Kong } \\
\text { dollar }\end{array}$ & $\begin{array}{l}\text { S. Korean } \\
\text { Won }\end{array}$ & $\begin{array}{c}\text { Singapore } \\
\text { dollar }\end{array}$ \\
\hline \multicolumn{8}{|c|}{ Single cross-hedge } \\
\hline \multirow[t]{3}{*}{ BP } & $\mathrm{U}$ & .0013 & .0017 & .0015 & .0000 & .0000 & .0002 \\
\hline & $\mathrm{N}$ & .0006 & .0005 & .0004 & .0019 & .0020 & .0012 \\
\hline & $\mathrm{P}$ & .0004 & .0004 & .0003 & .0000 & .0001 & .0001 \\
\hline \multirow[t]{3}{*}{$\mathrm{CD}$} & $\mathrm{U}$ & .0013 & .0017 & .0015 & .0000 & .0000 & .0002 \\
\hline & $\mathrm{N}$ & .0014 & .0014 & .0014 & .0002 & .0002 & .0003 \\
\hline & $\mathrm{P}$ & .0013 & .0015 & .0014 & .0000 & .0000 & .0002 \\
\hline \multirow[t]{3}{*}{ DM } & $\mathrm{U}$ & .0013 & .0017 & .0015 & .0000 & .0000 & .0002 \\
\hline & $\mathrm{N}$ & .0001 & .0004 & .0003 & .0014 & .0015 & .0009 \\
\hline & $\mathrm{P}$ & .0002 & .0005 & .0003 & .0000 & .0000 & .0001 \\
\hline \multirow[t]{3}{*}{ JY } & $\mathrm{U}$ & .0013 & .0017 & .0015 & .0000 & .0000 & .0002 \\
\hline & $\mathrm{N}$ & .0010 & .0017 & .0013 & .0008 & .0008 & .0005 \\
\hline & $\mathrm{P}$ & .0009 & .0015 & .0012 & .0000 & .0000 & .0001 \\
\hline \multirow[t]{3}{*}{ SF } & $\mathrm{U}$ & .0013 & .0017 & .0015 & .0000 & .0000 & .0002 \\
\hline & $\mathrm{N}$ & .0002 & .0007 & .0005 & .0014 & .0015 & .0009 \\
\hline & $\mathrm{P}$ & .0003 & .0007 & .0005 & .0000 & .0000 & .0001 \\
\hline \multicolumn{8}{|c|}{ Multiple cross-hedge } \\
\hline BP & $\mathrm{U}$ & .0013 & .0017 & .0015 & .0000 & .0000 & .0002 \\
\hline \multirow[t]{2}{*}{$\mathrm{DM} / \mathrm{JY} * *$} & $\mathrm{~N}$ & .0020 & .0017 & .0017 & .0040 & .0040 & .0028 \\
\hline & $\mathrm{P}$ & .0001 & .0004 & .0002 & .0000 & .0001 & .0001 \\
\hline $\mathrm{BP}$ & $\mathrm{U}$ & .0013 & .0017 & .0015 & .0000 & .0000 & .0002 \\
\hline DM & $\mathrm{N}$ & .0061 & .0059 & .0057 & .0091 & .0092 & .0072 \\
\hline $\mathrm{SF} / \mathrm{JY} * *$ & $\mathrm{P}$ & .0001 & .0004 & .0002 & .0000 & .0001 & .0001 \\
\hline $\mathrm{BP}$ & $\mathrm{U}$ & .0013 & .0017 & .0015 & .0000 & .0000 & .0002 \\
\hline DM & $\mathrm{N}$ & .0095 & .0095 & .0092 & .0169 & .0171 & .0144 \\
\hline JY & $\mathrm{P}$ & .0001 & .0004 & .0002 & .0000 & .0001 & .0001 \\
\hline BP & $\mathrm{U}$ & .0013 & .0017 & .0015 & .0000 & .0000 & .0002 \\
\hline $\mathrm{CD}$ & $\mathrm{N}$ & .0099 & .0095 & .0093 & .0174 & .0175 & .0148 \\
\hline DM & $\mathrm{P}$ & .0002 & .0004 & .0002 & .0000 & .0001 & .0001 \\
\hline
\end{tabular}

Note: The Japanese yen futures contact is used in constructing the multiple cross-hedges for the Asian currencies. $\mathrm{U}=$ unhedged portfolio variance of returns. $\mathrm{N}=$ naively hedged portfolio variance of returns, $\mathrm{P}=$ portfolio model hedged variance of returns. Test period is October 1989 to December 1992. 
For all minor currencies, the estimated hedge ratios are significantly different from one at the five-percent level. For example, Italian lira risk is minimized by going long .8238 German mark futures. Similarly, going long .1664 Swiss franc futures reduces Singapore dollar risk. Thus, a full hedge is not necessarily the best strategy for minimizing risk, which is consistent with Ederington's (1979) finding. In-sample hedging effectiveness is high for both single and multiple portfolio cross-hedges which clearly benefit from the diversification effect. In more than $80 \%$ of all portfolio cross-hedges (i.e., 45 out of 54), the coefficient of determination, HE, is greater than .5000.

Based on the variance of portfolio returns, as shown in table 5 , the naive and portfolio strategies are equally effective in reducing foreign exchange rate risk of the three minor European currencies with a single futures currency cross-hedge relative to an unhedged position.

However, a multiple currency futures cross-hedge results in risk reduction performance under a portfolio strategy superior to that of simply following a naive hedging rule. Failure of the naive strategy with a hedge ratio of one may be directly linked to the optimal cross-hedge ratios estimated under the portfolio model, which were found to be significantly different from one (see table 4). On the other hand, the greater variability of multiple hedge ratios, verified by the hedge ratio stability test (see table 3 ) and the fluctuating ex post hedge ratios seen across currencies and subperiods (see table 2), does not seem to significantly impact the cross-hedging performance.

For the single currency futures cross-hedges of the South Korean won and the Hong Kong dollar, neither the naive strategy nor the portfolio strategy result in significant risk reduction. In these two cases, the portfolio variance of returns is minimized by remaining unhedged. For the multiple currency futures cross-hedges, only Singapore dollar risk is significantly reduced under the portfolio strategy.

The significance of risk-reduction effectiveness of single and multiple currency cross-hedging is evaluated by comparing the variances of returns of not hedging with the variances of returns from the naive and portfolio strategy, respectively. According to the computed F ratios in table 6 (F-ratios (1) and Fratios (2)), both hedging strategies reduce risk relative to an unhedged position for single currency cross-hedges of the European currencies.

Risk reduction is statistically significant only when the portfolio strategy is employed to create multiple currency futures cross-hedges (F-ratios (2)). The single and multiple currency cross-hedges of the South Korean won and the Hong Kong dollar under the naive and portfolio strategies actually increased risk. 
TABLE 6. Comparative Analysis of Variance of Returns

\begin{tabular}{|c|c|c|c|c|c|c|c|}
\hline Futures & & $\begin{array}{c}\text { Greek } \\
\text { drachma }\end{array}$ & $\begin{array}{c}\text { Italian } \\
\text { lira }\end{array}$ & $\begin{array}{c}\text { Spanish } \\
\text { peseta }\end{array}$ & $\begin{array}{l}\text { Hong Kong } \\
\text { dollar }\end{array}$ & $\begin{array}{l}\text { S. Korean } \\
\text { Won }\end{array}$ & $\begin{array}{c}\text { Singapore } \\
\text { dollar }\end{array}$ \\
\hline \multicolumn{8}{|c|}{ Single Cross-Hedge } \\
\hline \multirow[t]{3}{*}{$\mathrm{BP}$} & $\mathrm{F}(1)$ & $2.14^{*}$ & $3.75^{*}$ & $4.22 *$ & .00 & .01 & .14 \\
\hline & $\mathrm{F}(2)$ & $2.93^{*}$ & $4.14^{*}$ & $5.02 *$ & .09 & .35 & $1.78^{*}$ \\
\hline & $\mathrm{F}(3)$ & 1.37 & 1.10 & 1.19 & $73.54 *$ & $31.42 *$ & $12.59 *$ \\
\hline \multirow[t]{3}{*}{$\mathrm{CD}$} & $\mathrm{F}(1)$ & .93 & 1.19 & 1.08 & .01 & .11 & .50 \\
\hline & $\mathrm{F}(2)$ & .98 & 1.14 & 1.08 & .92 & .90 & .96 \\
\hline & $\mathrm{F}(3)$ & 1.05 & .96 & 1.00 & $75.00 *$ & $8.31 *$ & $1.90^{*}$ \\
\hline \multirow[t]{3}{*}{ DM } & $\mathrm{F}(1)$ & $10.34 *$ & $3.82 *$ & $5.25^{*}$ & .00 & .02 & .20 \\
\hline & $\mathrm{F}(2)$ & $7.25 *$ & $3.65^{*}$ & $4.57 *$ & 1.01 & .67 & $1.85^{*}$ \\
\hline & $\mathrm{F}(3)$ & .70 & .96 & .87 & $644.55^{*}$ & $44.22 *$ & $9.15^{*}$ \\
\hline \multirow[t]{3}{*}{ JY } & $\mathrm{F}(1)$ & 1.29 & 1.04 & 1.20 & .00 & .03 & .37 \\
\hline & $\mathrm{F}(2)$ & 1.44 & 1.13 & 1.29 & .82 & .91 & $1.88^{*}$ \\
\hline & $\mathrm{F}(3)$ & 1.12 & 1.09 & 1.08 & $307.04 *$ & $33.13^{*}$ & $5.01 *$ \\
\hline \multirow[t]{3}{*}{ SF } & $\mathrm{F}(1)$ & $5.19 *$ & $2.38 *$ & $3.27 *$ & .00 & .01 & .19 \\
\hline & $\mathrm{F}(2)$ & $3.90 *$ & $2.34^{*}$ & $2.89 *$ & 1.01 & .77 & $1.73^{*}$ \\
\hline & $\mathrm{F}(3)$ & .75 & .98 & .88 & $655.91 *$ & $51.64 *$ & $9.00 *$ \\
\hline \multicolumn{8}{|c|}{ Multiple cross-hedge } \\
\hline BP & $\mathrm{F}(1)$ & .63 & .98 & .91 & .00 & .01 & .06 \\
\hline \multirow[t]{2}{*}{$\mathrm{M} / \mathrm{JY} * *$} & $\mathrm{~F}(2)$ & $10.79 *$ & $4.34 *$ & $9.46^{*}$ & .07 & .36 & $2.70 *$ \\
\hline & $\mathrm{F}(3)$ & $17.10^{*}$ & $4.43^{*}$ & $10.34 *$ & $119.58 *$ & $64.93 *$ & $42.89 *$ \\
\hline BP & $\mathrm{F}(1)$ & .21 & .29 & .27 & .00 & .00 & .02 \\
\hline DM & $\mathrm{F}(2)$ & $10.52 *$ & $4.33^{*}$ & $9.58^{*}$ & .06 & .34 & $2.74 *$ \\
\hline $\mathrm{SF} / \mathrm{JY} * *$ & $\mathrm{~F}(3)$ & $50.94 *$ & $14.87 *$ & $35.90 *$ & $266.77 *$ & $139.94 *$ & $112.26^{*}$ \\
\hline $\mathrm{BP}$ & $\mathrm{F}(1)$ & .13 & .18 & .17 & .00 & .00 & .01 \\
\hline $\mathrm{DM}$ & $\mathrm{F}(2)$ & $9.63 *$ & $4.04^{*}$ & $8.51 *$ & .06 & .35 & $2.57 *$ \\
\hline JY & $\mathrm{F}(3)$ & $72.74 *$ & $22.43 *$ & $51.03 *$ & $421.17 *$ & $270.59 *$ & $209.84 *$ \\
\hline BP & $\mathrm{F}(1)$ & .13 & .18 & .16 & .00 & .00 & .01 \\
\hline $\mathrm{CD}$ & $\mathrm{F}(2)$ & $8.19 *$ & $4.35^{*}$ & $8.86^{*}$ & .05 & .37 & $2.44^{*}$ \\
\hline DM & $\mathrm{F}(3)$ & $64.02 *$ & $24.13^{*}$ & $53.86^{*}$ & $361.46^{*}$ & $287.78^{*}$ & $204.81 *$ \\
\hline
\end{tabular}

Note: The Japanese yen futures contact is used in constructing the multiple cross-hedges for the Asia currencies. $F(1)=F-$ Ratios for unhedged vs. naively hedged. $F(2)=F-$ Ratios for unhedged vs. portfolio model hedged. $\mathrm{F}(3)=\mathrm{F}-$ Ratios for naively hedged vs. portfolio model hedged.*Statistically significant at the 5\% level. Test period is October 1989 to December 1992.

A comparison of the variances of returns of the naive strategy with the variances of returns of the portfolio strategy clearly shows that the portfolio strategy is superior in risk reduction to a simple naive hedge rule. The F-ratios (F-ratios (3) in table 6) are statistically significant at the five-percent level for all single and multiple currency futures cross-hedges of the minor Asian 
currencies examined. European currency risk is reduced in a statistical sense only with multiple currency futures cross-hedges under the portfolio strategy.

In summary, the results presented here for cross-hedging the currencies of minor European and Asian nations are generally consistent with the results for cross-hedging foreign exchange exposure of minor currencies. These findings also present empirical evidence for the cross-hedging strategies which are closely related to the institutional characteristics of the currency hedged. That is, the Greek drachma and the Singapore dollar are managed floating currencies, while the Spanish peseta and the Italian lira, for a portion of the sample period, belong to the Exchange Rate Mechanism of the European Monetary System. Those currencies pegged to a basket of various currencies, such as the South Korean won (until 1990), are most effectively cross-hedged with a basket hedge that reflects this policy. ${ }^{12}$ And foreign exchange rates which are linked to the U.S. dollar experience limited value change. Thus, there is no need to hedge the currency exposure, especially if the country's economy is relatively strong and a currency devaluation is highly unlikely.

\section{Summary and Conclusions}

This study presents empirical evidence on portfolio model cross-hedging with currency futures contracts. Single and multiple cross-hedges for European and Asian currencies, for which organized futures and forward markets are limited or nonexistent, were examined over the 1983 to 1992 sample period. Following Ederington's methodology, cross-hedging effectiveness was measured ex post, by using the OLS parameter estimates, and ex ante, by implementing prior least risk hedge ratios in subsequent hedge periods. The $e x$ post results generally support the cross-hedging strategy for all minor currencies examined, except the Hong Kong dollar. Comparison of hedging effectiveness measures shows a discrepancy between in-sample and out-ofsample performance. While the "drop" in cross-hedging effectiveness has not been determined to present a large problem for the minor European currencies, it is significant when cross-hedging the minor Asian currencies with currency futures. Here, the effectiveness measures are negative indicating that Asian currency risk is actually increased by the single and multiple currency futures

12. In February 1980, the Bank of Korea introduced a multi-currency basket peg system (MCBP). Under this mechanism, the U.S. dollar/Korean won exchange rate was "determined as the weighted average of two basket rates - an SDR basket and a trade-weighted basket, with an additional influence of an adjustment factor determined by the Bank of Korea" (Euromoney, June 1995, p. 10). As of March 1990, Korea operates under a market average rate system (MAR) which gives market forces a greater role in determining the exchange rate. 
cross-hedges relative to an unhedged position. These results, in turn, indicate that in-sample effectiveness measures overstate real-world hedging performance.

The cause for the lower ex ante hedging effectiveness appears to be hedgeratio variability. Examination of cross-hedge ratios across currencies and subperiods suggest that currency futures cross-hedging strategies would be somewhat susceptible to swings in performance. However, a formal hedge ratio stability test finds only the cross-hedge ratios for the minor European currencies to be unstable over time; the currency futures cross-hedge ratios for the Asian currencies are relatively stable. Yet, the intertemporal cross-hedge ratio instability does not appear to have a substantial impact on the crosshedging performance of currency futures for the European currencies.

Comparison of simulated currency futures cross-hedging strategies shows that the portfolio model yields superior risk reduction performance. The variance of hedged portfolio returns is minimized when cross-hedging the European currencies and the Singapore dollar. Application of the portfolio and naive hedge strategies to managing Hong Kong dollar and South Korean won risk, however, increases exposure to the hedger. Because of the diversification effect, multiple-currency futures cross-hedges outperform single-currency futures cross-hedges. Moreover, cross-hedging a single spot position with twocurrency futures positions is as effective as with five-currency futures positions.

The empirical results obtained from this study have important policy implications for international businesses that find themselves exposed to exchange rate risk which cannot be laid off directly in the currency futures and forward markets. In general, cross-hedging provides opportunities to minimize exchange rate risk at relatively low cost for the single non-traded currency. However, hedgers may have to accept lower cross-hedging performance $e x$ ante. Moreover, Asian currency risk cannot be effectively cross-hedged with currency futures even if the optimal cross-hedge ratios are stable over time. On the other hand, hedge-ratio instability may not necessarily affect cross-hedging performance. And optimal hedge parameters derived from the portfolio model appear to be quite useful, particularly in the case of multiple-currency futures cross-hedges. Although portfolio risk and return and statistical relationships are important, the currency hedger must also pay close attention to institutional details as well as strong economic relationships to create a "good" cross-hedge. 


\section{References}

Anderson, R. W., and Danthine, J.-P. 1981. Cross-hedging. Journal of Political Economy 89:1182-1196.

Benet, B. A. 1990a. Commodity futures cross-hedging of foreign exchange exposure. Journal of Futures Markets 10:287-306.

Benet, B. A. 1990b. Ex ante reduction of foreign exchange exposure via hedge-ratio adjustment. Review of Futures Markets 9:418-435.

Benet, B. A. 1992. Hedge period length and ex-ante futures hedging effectiveness: the case of foreign-exchange risk cross-hedges. Journal of Futures Markets 12:163-175.

Braga, F. S.; Martin, L. J.; and Meilke, K. D. 1989. Cross-hedging the Italian lira/US dollar exchange rate with deutsch mark futures. Journal of Futures Markets 9:87-99.

Braga, F. S., and Martin, L. J. 1990. Out of sample effectiveness of a joint commodity and currency hedge: The case of soybean meal in Italy. Journal of Futures Markets 10:229-245.

Dale, C. 1981. The hedging effectiveness of currency futures markets. Journal of Futures Markets 1:77-88.

Eaker, M. R., and Grant, D. M. 1987. Cross-hedging foreign currency risk. Journal of International Money and Finance 8:85-105.

Eaker, M. R., and Grant, D. M. 1989. Complex hedges: How well do they work?" Journal of Futures Markets 9:15-27.

Ederington, L. 1979. The hedging performance of the new futures markets. Journal of Finance 34:157-170.

Grammatikos, T., and Saunders, A. 1983. Stability and the hedging performance of foreign currency futures. Journal of Futures Markets 3:295-305.

Gujarati, D. 1978. Basic Econometrics. New York: McGraw-Hill.

Hill, J., and Schneeweis, T. 1981. A note on the hedging effectiveness of foreign currency futures markets. Journal of Futures Markets 1:660-663.

Hill, J., and Schneeweis, T. 1982. The hedging effectiveness of foreign currency futures. Journal of Financial Research 5:95-104.

Johnson, L. L. 1960. The theory of hedging and speculation in commodity futures. Review of Economic Studies 27:139-151.

Kwok, C. Y. 1987. Hedging foreign exchange exposures: Independent vs integrative approaches. Journal of International Business Studies (Summer): 33-51.

Lypny, G. J. 1988. Hedging foreign exchange risk and currency futures: Portfolio effects. Journal of Futures Markets 8:703-715.

Malliaris, A. G., and Urrutia, J. L. 1991. The impact of the lengths of estimation periods and hedging horizons on the effectiveness of a hedge: Evidence from foreign currency futures. Journal of Futures Markets 11:271-289.

Markowitz, H. 1952. Portfolio selection. Journal of Finance 7:77-91.

Marmer, H. S. 1986. Portfolio model hedging with Canadian dollar futures: A framework for analysis. Journal of Futures Markets 6:83-92.

Park, H.Y.; Lee, A.; and Lee, H.W. 1987. Cross-hedging performance of the U.S. 
currency futures market: The European monetary system currencies. Advances in Futures and Options Research 2:223-241.

Stein, J. L. 1961. The simultaneous determination of spot and futures prices. American Economic Review 1012-1025.

The 1995 Guide to Italy. 1995. Euromoney (January). London: Euromoney Publications PLC.

The 1995 Guide to Emerging Currencies. 1995. Euromoney(June). London: Euromoney Publications PLC.

The 1995 Guide to Greece. 1995. Euromoney (September). London: Euromoney Publications.

The 1996 Guide to Eemerging Market Currencies. 1996. Euromoney (June). London: Euromoney Publications PLC.

Witt, H. J.; Schroeder, T. C.; and Hayenga, M. L. 1987. Comparison of analytical approaches for estimating hedge ratios for agricultural commodities. Journal of Futures Markets 7:135-146. 